\title{
Mange barn og ungdommer har mye smerter
}

\author{
Mange friske barn har mye smerter. I en norsk studie oppga $60 \%$ av dem \\ mellom åtte og 18 år at de ofte hadde smerter.
}

$21 \%$ av norske barn har vedvarende eller kroniske smerter. Det viser Kristin Haraldstad i sin avhandling. Hun har undersøkt helserelatert livskvalitet og smerter hos barn og ungdom i alderen 8-18 år. 1238 barn ved 20 skoler i Østlandsområdet deltok i studien, som er en del av det europeiske KIDSCREEN-prosjektet.

- Ungdom i alderen 16-18 år rapporterte om mest smerter, og jentene sliter mest også når vi kontrollerte for menstruasjonssmerter. Hodepine var den vanligste smerten både for jenter og gutter, etterfulgt av magesmerter, rygg- og nakkesmerter. Mange oppgir at årsaken til smertene er sport og fritidsaktiviteter, for lite søvn og skolesituasjonen. Smerter påvirker dagliglivet og fører til søvnproblemer, fravær fra skole og fra fritidsaktiviteter, og bør derfor tas på alvor, sier Haraldstad.

Barn og ungdom med smerter hadde også signifikant lavere livskvalitet enn barn uten smerter.
- Både det å ha smerter, bli mobbet og ha et negativt kroppsbilde påvirket livskvaliteten, men kroppsbildet ser ut til å ha størst betydning. Overraskende nok var det ingen signifikant sammenheng mellom kroppsmasseindeks og livskvalitet, sier Haraldstad.

Hun fant også at det er lite samsvar mellom barnas og foreldrenes vurdering av smerter. Hos de minste overvurderer foreldrene barnas smerter, mens hos ungdommen er det omvendt.

- Det kan tyde på at foreldre i liten grad er klar over barnas plager. Uansett er det viktig å være oppmerksom på at smerte er et utbredt helseproblem blant barn og ungdom, sier Haraldstad.

\section{Eline Feiring}

eline.feiring@legeforeningen.no Tidsskriftet

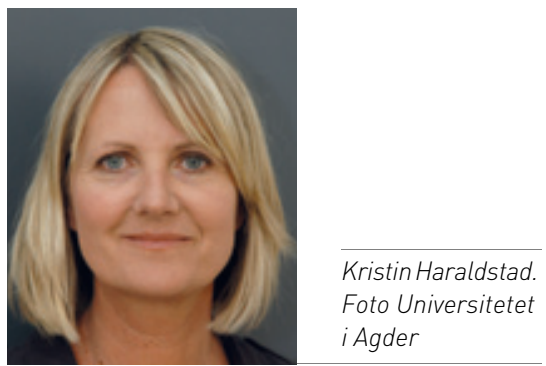

Disputas

Kristin Haraldstad disputerte for ph.d.-graden ved Universitetet i Bergen 21.6. 2011 med avhandlingen Health-related quality of life and pain in children and adolescents - the Norwegian KIDSCREEN study.

Ordforklaringer KIDSCREEN-prosjektet: Et prosjekt i forlengelsen av EUs rammeprogram «Quality of Life and Management of Living Resources.» Målet med prosjektet har vært å få til et europeisk samarbeid og utarbeide et standardisert instrument for å måle helserelatert livskvalitet hos barn og unge.

\section{Måling av lamotriginkonsentrasjon i blod}

\author{
Bruk av kombinerte p-piller kan føre til at serumkonsentrasjonen av \\ lamotrigin faller. Det samme skjer under svangerskap. Det er stor inter- \\ individuell variasjon i farmakokinetikk.
}

Lamotrigin (LTG) er det mest brukte antiepileptikum i Norge. Midlet brukes også ved behandling av psykiske lidelser. Ved bruk viser lamotrigin betydelig farmakokinetisk variasjon mellom individer. Dette kan skyldes sykdom, interaksjoner med andre legemidler, aldersavhengige forskjeller i metabolsk kapasitet eller hormonell påvirkning. Gjennom en serie kliniske studier og databaseanalyser har Arne Reimers identifisert og beskrevet disse faktorene og hvordan de påvirker farmakokinetikken til lamotrigin.

- Avhandlingen viser at de fleste psykofarmaka trygt kan kombineres med lamotrigin. Men vi ser at etinyløstradiolet i p-piller reduserer lamotriginserumkonsentrasjonen med over $50 \%$. Dette kan føre til tap av anfallskontroll og behov for å øke lamotrigindosen. P-piller som kun inneholder et progestin, innvirker ikke på lamotriginet. Det er flest kvinner som bruker lamotrigin, derfor er dette så viktig, sier Reimers.
Aktiviteten av enzymet UGT1A4 er lav hos barn, men øker med alderen. Variasjonen mellom individer av samme alder er stor, jo yngre, desto større. Dette har betydning for lamotriginmetabolismen. Barn og unge som bruker lamotrigin bør derfor følges tett, både klinisk og med serumkonsentrasjonsmålinger.

- Våre funn viser at det er nyttig å måle serumkonsentrasjoner av lamotrigin, spesielt hos barn og eldre, men også hos pasienter som bruker andre legemidler, for eksempel kombinerte p-piller. Svangerskap fører til et raskt og stort fall av lamotriginserumkonsentrasjonen allerede tidlig i første trimester, og den kan synke med over $50 \%$. Det er viktig å ha god kjennskap til dette ved behandling av kvinner som ønsker å bli gravide, sier Reimers.

\section{Anne Forus}

anneforus@hotmail.com

Tidsskriftet

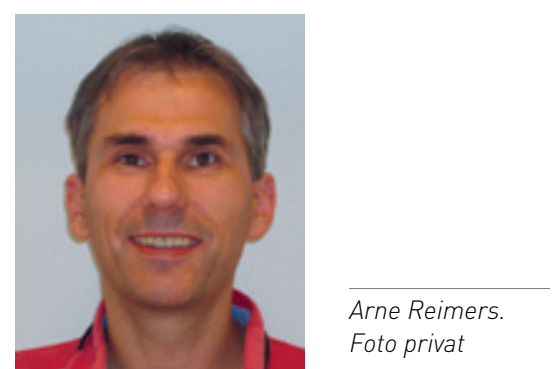

Disputas

Arne Reimers forsvarte avhandlingen Clinical pharmacology of lamotrigine for graden dr.philos. ved Norges teknisk-naturvitenskapelige universitet 14.6. 2011.

\section{Ordforklaringer}

Farmakokinetikk: Opptak, distribusjon, metabolisme og utskilling av legemidler i kroppen. UGT1A4: UDP-glukuronosyl-transferase 1A4, enzym involvert i metabolisering av lamotrigin ved å katalysere konjugering med glukuronsyre. 